\title{
Prolonged coexistent central diabetes insipidus and cerebral salt wasting syndrome following neurosurgery
}

\author{
D. López de Lara ${ }^{1}$, B. Joyanes ${ }^{1}$, A. Llaneza ${ }^{1}$, O. Pérez ${ }^{1}$, B. Llorente ${ }^{1}$, I. Runkle ${ }^{2}$ \\ ${ }^{1}$ Department of Pediatrics, Hospital Clínico San Carlos, Madrid, Spain \\ ${ }^{2}$ Department of Endocrinology, Hospital Clínico San Carlos, Madrid, Spain \\ Email: dldlara@yahoo.es
}

Received 8 January 2013; revised 10 February 2013; accepted 18 February 2013

Copyright (C) 2013 D. López de Lara et al. This is an open access article distributed under the Creative Commons Attribution License, which permits unrestricted use, distribution, and reproduction in any medium, provided the original work is properly cited.

\begin{abstract}
The coexistence of different water homeostasis abnormalities following neurosurgery represents a diagnostic and therapeutic challenge for intensive care units. This paper reports the case of a 13 year-old boy who underwent surgery for a suprasellar tumour and, immediately after surgery, developed a cerebral abscess, persistent diabetes insipidus (DI) as well as cerebral salt wasting syndrome (CSWS). The early onset of CSWS following DI has been associated with a poor prognosis and increased mortality. In cases in which these abnormalities coexist, the increased polyuria secondary to the rise in natriuresis associated with CSWS might be erroneously interpreted as a sign of poor control of the DI, thereby leading to therapeutic mistakes. Treatment basically consists of restoring electrolytes and the joint administration of desmopressin and fludrocortisone.
\end{abstract}

Keywords: Electrolyte Disorder; Diabetes Insipidus; Cerebral Salt Wasting Syndrome; Neurosurgery

\section{INTRODUCTION}

Hydroelectrolytic abnormalities are reported in 15\% $45 \%$ of children following intracranial surgery, with Diabetes Insipidus (DI), cerebral salt-wasting syndrome (CSW), the syndrome of inappropriate secretion of antidiuretic hormone (SIADH) and central adrenal insufficiency as the primary causes [1-3]. DI is the most common, with a post-surgery incidence of $8 \%-21 \%$ in patients operated on for intracranial tumours [1,4-7] CSW is less frequent, found in $4 \%$ of children following neurosurgery [1].

Infrequently following the onset of DI, CSW may also appear $[8,9]$ posing a diagnostic and therapeutic challenge. We present a case of a patient who presented pro- longed DI and CSW simultaneously following neurosurgery for a suprasellar tumor.

\section{CLINICAL CASE}

We describe the case of a 13 year-old boy who presented repeated syncope following urination over a two-week period. He was moderately overweight (bodyweight 75 kg [p85]; BMI 28 [p97]; height $160 \mathrm{~cm}$ [p15]) at Tanner stage 3. Physical examination and personal and family history revealed no findings of interest. The patient's visual field, fundus and echocardiogram were normal. Cranial CT with intravenous contrast revealed a $2.5 \mathrm{~cm}$ mass occupying the suprasellar cistern. Natremia was $137 \mathrm{mEq} / \mathrm{l}$, urinary osmolality $486 \mathrm{mOsm} / \mathrm{kg}$, and Uricemia $7.2 \mathrm{mg} / \mathrm{dl}$. GH was deficient, with a peak of 1.6 $\mathrm{ng} / \mathrm{dl}$ following iv clonidine and $1.5 \mathrm{ng} / \mathrm{dl}$ following iv glucagon; with IGF-1 of $180 \mathrm{ng} / \mathrm{ml}$ and $145 \mathrm{ng} / \mathrm{ml}$ respectively. Cortisol was 209 ng/ml (N: 50 - 210), ACTH $62 \mathrm{pg} / \mathrm{ml}$, basal LH $5.7 \mathrm{mUI} / \mathrm{ml}$, basal FSH $10.5 \mathrm{mUI} / \mathrm{ml}$, TSH $2.70 \mathrm{mUI} / \mathrm{ml}$, T4L $1.20 \mathrm{ng} / \mathrm{dl}$, and prolactin 217 $\mathrm{mUI} / \mathrm{ml}$ (N: 79 - 218). MRI confirmed a suprasellar mass with an hourglass morphology crossing the pituitary diaphragm (Figure 1), with craniopharyngioma as a first diagnostic possibility. Treatment with hydrocortisone was begun on the evening before surgery. 32 hours following surgery, the patient presented an increase in urine output, rising from a diuresis of 600 cc over 5 hours to 3200 cc over 5 hours ( $8 \mathrm{cc} / \mathrm{kg} /$ hour), while receiving an iv infusion of $200 \mathrm{mg}$ of hydrocortisone over $24 \mathrm{~h}$, iv isotonic saline and $5 \%$ glucose for a total iv administration of 3000 cc in 24 hours. During this time natremia rose from 133 to $150 \mathrm{mEq} / \mathrm{l}$. Na in urine during the 5-hour-period pre-frank polyuria was $50 \mathrm{mEq} / \mathrm{l}$ or 6 $\mathrm{mEq} /$ hour. With a diagnosis of DI, $30 \mathrm{mcg}$ of ddAVP were administered, normalizing natremia (Table 1).

On the second day post-surgery, the patient initiated oral water tolerance, and presented a diuresis of $3000 \mathrm{cc}$ 
Table 1. The related data of the patient before and after the suergery.

\begin{tabular}{|c|c|c|c|c|c|c|c|}
\hline & $\begin{array}{c}1 \text { week } \\
\text { pre-surgery }\end{array}$ & Day of surgery & $\begin{array}{c}1 \text { day } \\
\text { post-surgery }\end{array}$ & $\begin{array}{c}2^{\circ} \text { day } \\
\text { post-surgery }\end{array}$ & $\begin{array}{c}4^{\circ} \text { day } \\
\text { post-surgery }\end{array}$ & $6^{\circ}$ day post-surgery & $\begin{array}{c}30 \text { days } \\
\text { post-surgery }\end{array}$ \\
\hline Clinical volemia & Normovolemia & Normovolemia & Iniciating DH & Normovolemia & $\mathrm{DH}$ & $\gg \mathrm{DH}$ & Normovolemia \\
\hline $\begin{array}{l}\text { Na plasma } \\
(\mathrm{mEq} / \mathrm{L})\end{array}$ & 137 & 135 & From 133 to 150 & 141 & From 143 to 134 & From 134 to 121 & 135 \\
\hline $\begin{array}{l}\text { Osm plasma } \\
(\mathrm{mOsm} / \mathrm{Kg})\end{array}$ & & 284 & From 284 to 300 & 292 & & 263 & 287 \\
\hline Diuresis (ml/kg/h) & & 2.5 & From 2.5 to 8 & 1,5 & 8 & 8 & 1.5 \\
\hline Na urine $(\mathrm{mEq} / \mathrm{h})$ & & & 2 & 11,5 & & 167 & 6.6 \\
\hline Na urine $(\mathrm{mEq} / \mathrm{L})$ & & & 17 & 56 & & 209 & 64 \\
\hline $\begin{array}{l}\text { Osm urine } \\
\text { (mOsm/kg) }\end{array}$ & 486 & 600 & $<100$ & & & 750 & 300 \\
\hline Urine density & 1010 & & 1000 & & & 1025 & 1020 \\
\hline iv fluids & & $\begin{array}{l}\text { 2/3 5\% glucose; } \\
\text { 1/3 isotonic } \\
\text { saline: } 100 \mathrm{ml} / \mathrm{h}\end{array}$ & $\begin{array}{l}\text { 2/3 5\% glucose; } \\
\text { 1/3 isotonic } \\
\text { saline: } 100 \mathrm{ml} / \mathrm{h} \\
\text { to } 200 \mathrm{ml} / \mathrm{h}\end{array}$ & $\begin{array}{l}\text { 2/3 5\% glucose; } \\
\text { 1/3 isotonic } \\
\text { saline: } 135 \mathrm{ml} / \mathrm{h}\end{array}$ & $\begin{array}{l}\text { 2/3 5\% glucose; } \\
\text { 1/3 isotonic } \\
\text { saline: } 130 \mathrm{ml} / \mathrm{h}\end{array}$ & $\begin{array}{c}\text { 2/3 5\% glucose; } 1 / 3 \\
\text { isotonic saline: } 135 \\
\mathrm{ml} / \mathrm{h}+\text { isotonic } \\
\text { saline } 50 \mathrm{ml} / \mathrm{h}\end{array}$ & \\
\hline $\begin{array}{l}\text { oral fluid intake } \\
\text { (ml) }\end{array}$ & & 0 & 0 & 700 & 150 & 0 & 2500 \\
\hline $\begin{array}{l}\text { Oral intake of } \\
\mathrm{NaCl}\end{array}$ & & 0 & 0 & 0 & 0 & 0 & $\begin{array}{l}\text { high salt diet } \\
\text { (aprox. } 18 \mathrm{~g} \mathrm{NaCl} \text { ) }\end{array}$ \\
\hline Balance & & Balance & Negative & Positive & Negative & Negative++ & Balance \\
\hline DDAVP i.n (mcg) & & 0 & 30 & 30 & $30 \times 2$ & $30 \times 2$ & $3 \mathrm{mg} / 8 \mathrm{~h}$ \\
\hline Fludrocortisone & & 0 & 0 & 0 & 0 & \multicolumn{2}{|c|}{$0.1 \mathrm{mg}-0-0.1 \mathrm{mg} 0.1 \mathrm{mg}-0-0.1 \mathrm{mg}$} \\
\hline Thyroid hormones & $\begin{array}{l}\text { TSH 2.63; } \\
\text { T4L 9.26 }\end{array}$ & & & & $\begin{array}{c}\text { TSH 1.94; T4L } \\
8.03\end{array}$ & & \\
\hline Blood count & $\begin{array}{c}\text { Hb } 14.9 \text { mg/L; } \\
\text { Hct. } 43.9\end{array}$ & $\begin{array}{c}\text { Hb } 12.1 \mathrm{mg} / \mathrm{L} ; \\
\text { Hct } 35.1\end{array}$ & & $\begin{array}{c}\text { Hb } 10.9 \text { mg/L; } \\
\text { Hct } 31\end{array}$ & & Hb 16 mg/L; Hct 45 & \\
\hline
\end{tabular}

over 24 hours (1.5 cc /kg/hour) on ddAVP therapy, maintaining $200 \mathrm{mg}$ iv of hydrocortisone over $24 \mathrm{~h}$, as well as 3000 cc iv fluids.. However, in a urine spot analysis from a 2-hour period with a total diuresis of 500cc during the evening, natriuresis was elevated, with $56 \mathrm{mEq} / \mathrm{l}$ (total $23 \mathrm{mEq}$ in 2 hours or $11.5 \mathrm{mEq} /$ hour).

On day 3 the patient showed confusion with a tendency towards somnolescence and a $39^{\circ} \mathrm{C}$ fever. A cerebral TC revealed an abscess in the left parieto-frontal lobe (Figure 2). Intravenous meropenem and vancomycin were intiated. Blood cultures were negative.

On day four, with a total of 2900 cc iv saline and glucose, and 550 cc of oral liquids, the patient's natremia dropped from 143 to 134, with a serum uric acid level of $3.8 \mathrm{mg} / \mathrm{dl}$, and an increase in diuresis from 50 cc over 2 hours to 1100 over 3 hours, in spite of maintenance of ddAVP doses (Table 1). Hemoglobin (Hb) rose to 11.4 g/l and Hematocrit (Hct) to $33.3 \mathrm{mg} / \mathrm{dl}$ from 10.4 and 30.7 respectively. Thyroid hormone levels were normal, with a TSH level of $1.94 \mathrm{mUI} / \mathrm{ml}$, and T4l of $8.03 \mathrm{ng} / \mathrm{dl}$. Hydrocortisone infusion had been reduced to a $20 \mathrm{mg}$ iv bolus every 8 hours, and the last dose had been administered 3 hours before the reinitiation of polyuria. In spite of maintained polyuria, serum Na did not increase, dropping initially from 134 at $8 \mathrm{AM}$ to $125 \mathrm{mEq} / \mathrm{l}$ at $6 \mathrm{PM}$ and to $121 \mathrm{mEq} / \mathrm{l}$ at $9 \mathrm{PM}$, on the 5th day, coinciding with an increase of $\mathrm{Hb}$ to $16 \mathrm{~g} / \mathrm{l}$ and Hct to $45 \mathrm{mg} / \mathrm{dl}$ and a frank rise in natriuresis: $209 \mathrm{mEq} / \mathrm{l}$, in a diuresis of 800 cc from 6 PM to 9PM (167 mEq/hour). The patient had received an oral dose of $20 \mathrm{mg}$ of hydrocortisone at breakfast, and $10 \mathrm{mg}$ of hydrocortisone at dinner, as well as 3500 in iv fluids. The patient vomited several times during the day, interrupting oral fluid intake, and presented clinical signs of dehydration. 


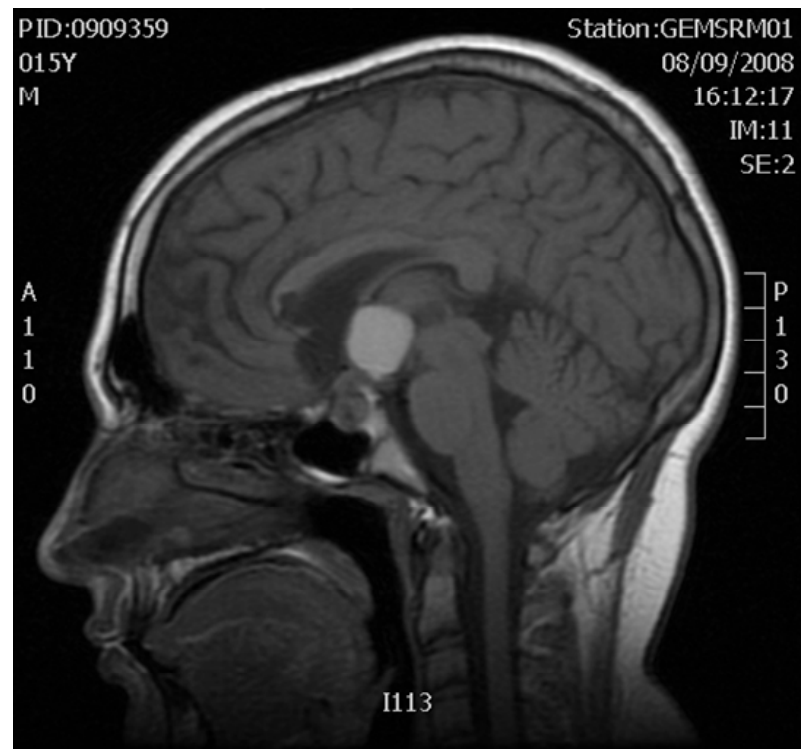

Figure 1. NMR with intravenous contrast showing a lesion (maximum diameter $1.6 \mathrm{~cm}$ ) of bilobed appearance with sellar and suprasellar components. These findings are compatible with a craniopharyngioma.

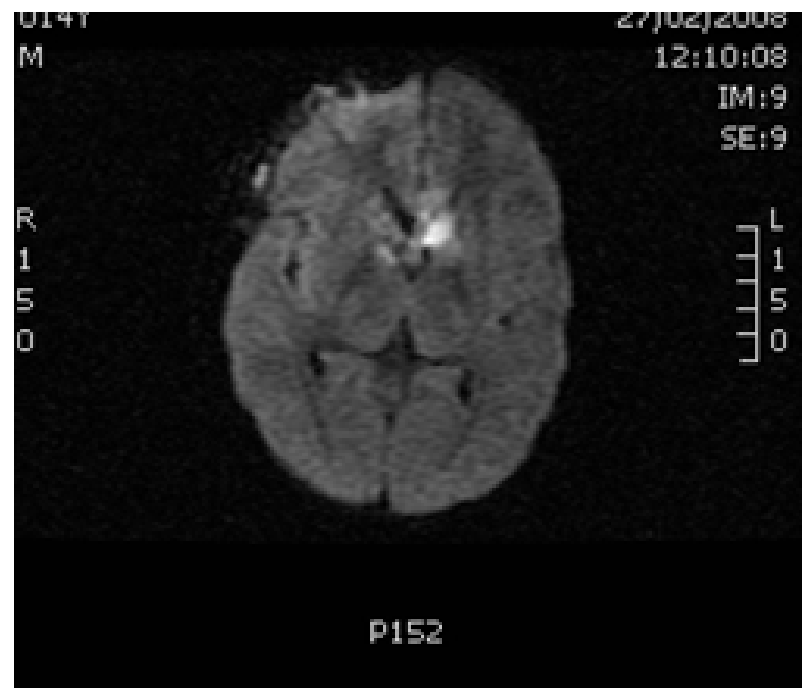

Figure 2. CT scan with intravenous contrast showing a cystlike mass $(2.1 \times 1.2 \mathrm{~cm})$; the contrast shows restricted diffusion. Findings compatible with an abscess.

On the following morning, (day 6), clinical dehydration persisted, natremia was $123 \mathrm{mEq} / \mathrm{l}$, aldosterone levels were clearly suppressed at $22 \mathrm{pg} / \mathrm{ml}(\mathrm{N}$ from 97 to 626 ) as was renin at $1 \mathrm{pg} / \mathrm{ml}$ ( $\mathrm{N}$ from 3 to 33). Natremia improved following $3 \%$ iv hypertonic saline, increased iv isotonic saline, and a higher dose of hydrocortisone (60 $\mathrm{mg}$ iv bolus every $12 \mathrm{~h}$ ). DdAVP administration remained constant.

Over the following days, Na levels were normalized, and iv isotonic saline infusion was maintained. However, $0.4 \mathrm{mg}$ of oral fludrocortisone was needed to maintain normal natremia once iv saline was interrupted. The patient later stayed on fludrocortisone and ddAVP, and hydrocortisone dose was gradually tapered. A month following surgery ACTH and cortisol levels were normal, but hyporeninemic hypoaldosteronism persisted (Table 1). Following 4 weeks of treatment with meropenem and vanccomycin, the patient received a 4-week cycle of linezolid and metronidazol. Later CT images showed the abscess to have been resolved. Histological exam of the original tumor revealed a craniopharyngioma.

18 months following surgery, the patient still needs ddAVP (oral desmopressin $0.3 \mathrm{mg} /$ day in three doses) and fludrocortisone (0.1 mg every $12 \mathrm{~h}$ ), together with oral salt supplements to maintain normal levels of natremia and diuresis, but natriuresis remains high at up to $219 \mathrm{mEq} / \mathrm{l}$. MRI af followup at 18 months reveals reapparition of the tumor.

\section{DISCUSSION}

Central DI is characterised by ADH hyposecretion, inducing hypernatremia and polyuria [10]. If the thirst mechanism is altered, the patient has insufficient access to water, or administration of liquids is inadequate, severe hypernatremic dehydration can occur. Patients are particularly at risk following neurosurgery, and should be carefully monitored [2]. Treatment is based on adequate water restoration, and the administration of desmopressin [3].

Following the onset of DI, CSW may also appear, characterised by increased natriuresis with a secondary increment of aquaresis giving rise to polyuria and dehydration. Hyponatremia and hipouricemia follow increased natriuresis and uricosuria [8,11]. When DI and CSW present simultaneously in the same patient [12-14] the consequent CSW-induced increase in polyuria may be erroneously interpreted as poor control of DI. However in DI hypernatremia is characteristic, whereas in CSW natremia typically decreases, and an increased desmopressin dose only worsens hyponatraemia.

Since hyponatremia in CSW is typically accompanied by hypouricemia, it can be confused with SIADH [8, 12,15] or excessive doses of ddAVP. However, CSW patients can be distinguished by their hypovolemia, hyponatremia worsening upon water restriction, improving with iv isotonic saline, coinciding with an increased diuresis and a rise in parameters such as $\mathrm{Hb}$ and Hct. Addison's Disease (AD) can also be accompanied by dehydration, hyponatremia, and increased natriuresis. However serum uric acid levels rise in AD, and renin levels are frankly increased, while our patients's hyporeninemic hypoaldosteronism is typical of CSW [11] Central adrenal failure is even less probable, given the patient's dehydration, and since the initial rise in diuresis 
and descent in natremia occurred shortly following an iv bolus of $20 \mathrm{mg}$ hydrocortisone, effectively ruling out both types of adrenal insufficiency.

Thefore the key for the diagnosis of CSW in our patient was the development of a negative Na balance, increased diuresis and dehydration [9] in the absence of adrenal failure.

The early onset of CSW following DI (i.n < 4 days), as occurred in this patient, has indicated a poorer prognosis [14]. However, our patient progressed satisfactorily. Treatment of CSW cannot simply be based on $\mathrm{Na}$ and water: high dose fludrocortisone (0.2 - $0.4 \mathrm{mg} /$ day) is often indicated [16]. The duration of CSW in not often reported. Rarer still are reports mentioning prolonged CSWS [17-19]. No case has persisted as long as in our patient, in whom, 18 months following surgery, interruption of fludrocortisone treatment is impossible without a significant increase in diuresis and a tendency towards hiponatremia, no doubt because of tumor relapse.

\section{CONCLUSION}

Patients who have undergone intracranial surgery can present both DI and CSW simultaneously. The recognition of this potential combination has important therapeutic consequences, and requires close monitoring during the postoperative period in an intensive care unit, with special attention to Na fluctuations, always bearing in mind the context in which these occur. In some cases, the association of both DI and CSW can be prolonged and persist for months.

\section{REFERENCES}

[1] Segura, S., Balaguer, M., Cambra, F.J., Zambudio, S., Martín, J.M. and Palomeque, A. (2007) Fluid and electrolyte disorders following surgery for brain tumors. Anales de Pediatría, 67, 225-230.

[2] Srivatsa, A. and Majzoub, J. (2007) Disorders of water homeostasis. In: Fima, L., Ed., Pediatric Endocrinology, 5th Edition, Informa Healthcare, Boston, Massachusetts, 651-692.

[3] Bergadá, I. (2009) Trastornos de la hipófisis posterior. In: Pombo, Ed., Tratado de Endocrinología Pediátrica, 4th Edition, McGraw-Hill Interamericana, Madrid, 336-344.

[4] Murillo, M.A., Sanchez, E., Reina, A., Márquez, C. and Lopez, J. (2005) Tumores del sistema nervioso central: Manejo perioperatorio. Anales de Pediatría, 62, 500-501.

[5] Hiranrat, P., Katavetin, P., Supornsilchai, V., Wacharasindhu, S. and Srivuthana, S. (2003). Water and sodium disorders in children undergoing surgical treatment of brain tumors. Journal of the Medical Association of Thailand, 86, 152-159.

[6] Cardoso, A.P., Dragosavac, D., Araujo, S., Falcao, A.L., Terzi, R.G., Castro, M., Marcondes, F.G., Melo, T.G., Oliveira, R.A. and Cintra, E.A. (2007) Syndromes related to sodium and arginine vasopressin alterations in postoperative neurosurgery. Arquivos de Neuro-Psiquiatria, 65, 745-751. doi:10.1590/S0004-282X2007000500003

[7] Santana, L., Hernández-Medina, E., Villanueva, A. And Sánchez-Palacios, M. (2006) Salt waste syndrome in subarachnoid hemorrhage. Nefrologia, 26, 513.

[8] Palmer, B.F. (2009) Cerebral salt wasting. Uptodate review version 17.3.

[9] Singh, S., Bohn, D., Carlotti, A.P., Cusimano, M., Rutka, J.T. and Halperin, M.L. (2002) Cerebral salt wasting: Truths, fallacies, theories, and challenges. Critical Care Medicine, 30, 2575-2579.

[10] Ghirardello, S., Hopper, N., Albanese, A. and Maghnie, M. (2006). Diabetes Insipidus in craniopharyngioma: Postoperative management of water and electrolyte disorders. Journal of Pediatric Endocrinology \& Metabolism, 1, 413-421.

[11] Taplin, C.E., Cowel, C.T., Silink, M. and Ambler, G.R. (2006) Fludrocortisone therapy in cerebral salt wasting. Pediatrics, 118, e1904-e1908.

[12] Decaux, G., Prospert, F., Namias, B. and Soupart, A. (1990). Utility of serum uric acid determination in the differential diagnosis between central diabetes insipidus and primary polidipsia. Journal of the American Society of Nephrology, 33, 174-178

[13] Kurtoglu, S., Atabek, M.E., Keskin, M., Patiroglu, T., Kumandas, S. and Topaloglu, N. (2006). Rhabdimyosarcoma with coexistent diabetes insipidus and cerebral salt wasting as postoperative complication. Pediatrics International, 48, 79-81. doi:10.1111/j.1442-200X.2006.02161.X

[14] Von Bismarck, P., Ankermann, T., Eggert, P., Claviez, A. and Fritsch, M.J. (2006) Diagnosis and management of cerebral salt wasting in children: the role of atrial natriuretic peptide (ANP) and brain natriuretic peptide (BNP). Child's Nervous System, 22, 1275-1281. doi:10.1007/s00381-006-0091-x

[15] Rabinstein, A.A. and Wijdicks, E.F. (2003) Hyponatremia in critically ill neurological patients. Neurologist, 9, 290-300. doi:10.1097/01.nrl.0000095258.07720.89

[16] Lin, J.J., Lin, K.L., Hsia, S.H., Wu, C.T. and Wang, H.S. (2009) Combined central diabetes insipidus and cerebral salt wasting syndrome in children. Pediatric Neurology, 40, 84-87. doi:10.1016/j.pediatrneurol.2008.09.010

[17] Jiménez, R., Casado-Flores, J., Nieto, M. and GarcíaTeresa, M.A. (2006) Cerebral salt wasting syndrome in children with acute central nervous syndrome injury. $P e$ diatric Neurology, 35, 261-263. doi:10.1016/j.pediatrneurol.2006.05.004

[18] Oruckaptan, H.H., Ozisik, P. and Akalan, N. (2000) Prolonged cerebral salt wasting syndrome associated with the intraventricular dissemination or brain tumors. Pediatric Neurology, 33, 16-20. doi:10.1159/000028969

[19] Ohtonari, T., Hashimoto, M., Urasaki, E., Yokota, A., Araki, S., Asayama, K. and Shirahata, A. (2005) Prolonged cerebral salt wasting following craniopharyngioma surgery and posterior reversible encephalopathy syndrome: A case report. No To Shinkei, 57, 57-63. 